\title{
WhAT EXPLAINS THE INCREASED UTILIZATION of Powder River Basin Coal in Electric Power Generation?
}

\author{
Shelby Gerking ANd Stephen F. Hamilton
}

\begin{abstract}
This article examines possible explanations for increased utilization of Powder River Basin (PRB) coal in electric power generation that occurred over the last two decades. Did more stringent environmental policy motivate electric power plants to switch to less polluting fuels? Or, did greater use of PRB coal occur because relative price changes altered input markets in favor of this fuel. A key finding is that factors other than environmental policy such as the decline in railroad freight rates together with elastic demand by power plants were major contributors to the increased utilization of this fuel.
\end{abstract}

Key words: environmental Policy, freight rates, powder River Basin coal, railroad transportation costs.

Since the inception of the Clean Air Act in $1970, \mathrm{SO}_{2}$ emissions in the United States declined by $50 \%$ at less than $10 \%$ of the originally estimated cost (Kerr 1998). Much of this reduction appears to have occurred through substitution at electric utilities from high-sulfur coal to cleaner-burning inputs of low-sulfur coal from the Powder River Basin (PRB) of Wyoming and Montana. Over the twelve-year period 1990-2002, PRB coal production more than doubled and the number of utilities burning this fuel more than tripled, while coal production in the high-sulfur Illinois Basin (Illinois, Indiana, and West Kentucky) declined by $42 \%$. Identifying the relative importance of factors that can explain these stylized facts is essential to understanding the role of environmental policy to control $\mathrm{SO}_{2}$ emissions.

This article weighs several possible explanations for the dramatic increase in utiliza-

Shelby Gerking is professor of economics, University of Central Florida, Orlando, and Stephen F. Hamilton is associate professor of economics, California State Polytechnic University, San Luis Obispo.

This research is partially supported by an appropriation from the Wyoming Legislature (1999 Wyoming Session Laws, Chapter 168, Section 3). Results presented may or may not reflect the views of public officials in the State. The author is grateful to CentER, Tilburg University, and the Department of Spatial Economics, Free University of Amsterdam, which provided hospitality while portions of this article were written. The authors received numerous helpful comments on earlier drafts from Spencer Banzhaf, Meghan Busse, Michael Caputo, Michael Greenstone, John Horowitz, Charles Kolstad, seminar participants at UC Berkeley, UC Santa Barbara, the University of Maryland, the University of Nebraska, the University of Massachusetts, and participants in the 2004 NBER Summer Institute Workshop on Environmental Economics. tion of low-sulfur PRB coal to generate electric power. One explanation for increased PRB coal use, emphasized by the U.S. Department of Energy (2000), is that more stringent environmental policy motivated electric utilities to switch to less polluting fuels. The Clean Air Act Amendments of 1990 lowered $\mathrm{SO}_{2}$ emissions limits for the dirtiest power plants and allowed for expanded compliance options through the landmark introduction of marketable emissions permits. An alternative explanation is that greater use of PRB coal may have occurred because of relative price changes that were unrelated to innovations in environmental policy. The period 1985-2000 witnessed substantial declines in the mine-mouth price of PRB coal, railroad freight rates, and rail transportation costs. These factors potentially induced existing buyers to increase their use of this fuel and attracted new buyers through an expansion of railroad service territories.

The analysis is framed around a model of railroad behavior for two reasons. ${ }^{1}$ First, transportation is a significant source of value-added in the market for delivered, low-sulfur coal. PRB coal is shipped almost entirely by rail and transportation costs run as high as $80 \%$ of delivered prices. Second, the small number of railroads that deliver PRB coal suggests

\footnotetext{
${ }^{1}$ Numerous recent studies (see, e.g., Joskow, Schmalensee, and Bailey 1998; Montero 1999; and Carlson et al. 2000) have examined performance of federal environmental policy by looking at the market for emission permits. For a detailed discussion of the political economy of allocating emission permits, see Joskow and Schmalensee (1998).
} 
a potential for market power that can compromise the effectiveness of environmental policy. $^{2}$

It turns out that the extent of railroad market power is crucial to sorting out the importance of the various factors that led to increased utilization of PRB coal. Consider, for instance, the effectiveness of $\mathrm{SO}_{2}$ emission controls in stimulating input substitution favoring low sulfur fuels at electric utilities. If the railroad sector is competitive, $\mathrm{SO}_{2}$ emission controls bid up delivered PRB coal prices, encouraging deliveries of PRB coal to more distant utilities, while leaving deliveries to existing buyers unchanged. If the railroad sector is noncompetitive, $\mathrm{SO}_{2}$ policy similarly expands the geographic market for PRB coal; however, because demand facing railroads is more elastic at greater shipping distances, the entry of new utilities in the service region alters the ability of railroads to spatially price discriminate. Shipments to existing buyers, as a consequence, are reduced.

The model of railroad behavior is tested using unique data on 353 PRB coal shipment routes for the period 1988-1999. Two key findings emerge from the empirical analysis. First, the geographic market area for PRB coal expanded largely because of declines in rail transportation costs and the mine-mouth price of PRB coal, and to a lesser extent because of more stringent environmental policy including the introduction of $\mathrm{SO}_{2}$ emission permits. Second, the demand for PRB coal is price elastic, so the decline in delivered prices that occurred over this period provided incentives for power plant operators to substitute toward the use of PRB coal throughout the railroad service territory. Controlling for shipping distance, the empirical results show that electric generating plants with Table A units-the units singled out in the Clean Air Act Amendments of 1990 for immediate $\mathrm{SO}_{2}$ emission reductionpaid no higher freight rates and bought no more PRB coal than plants without Table A units. These results, differ from recent findings of Busse and Keohane (2007) who find an important role for environmental policy in

\footnotetext{
${ }^{2}$ More generally, the analysis also contributes to the literature on market performance in the transportation sector and provides a rare glimpse into how market power is exercised over space. Market performance has been examined in the airline industry (see, e.g., Borenstein 1989, 1990; Brander and Zhang 1990; Kim and Singal 1993) and in the trucking industry (Savage 1995). The potential to exercise market power in rail transportation has been recognized since at least the case of Standard Oil (see Granitz and Klein 1996).
}

shaping coal market outcomes, but nonetheless are broadly consistent with: (1) Ellerman and Montero (1998) and Ellerman et al. (2000) who found that environmental policy was not an important contributor to increased utilization of PRB coal in electric power generation and (2) Greenstone (2002), who argues that environmental policy was not a major factor leading to the observed decline in $\mathrm{SO}_{2}$ emissions.

\section{Background}

The model developed in the following section has three types of agents (mines, railroads, and electric utilities) and two types of markets (a market between mines and railroads and a series of spatially distributed markets between railroads and individual utilities). Key aspects of the model are: (1) mines are perfect competitors, (2) railroads potentially exercise market power in the determination of freight rates, and (3) utilities have no bargaining power. These aspects differ in several respects from the way industry structure has been conceived in earlier studies, and the purpose of this section is to reconcile these views.

In the 1980s, leading studies of the PRB coal market suggested at least four potentially important sources of noncompetitive behavior among mines, railroads, and utilities. First, Atkinson and Kerkvliet (1986) argued that mines may have market power because of entry barriers that arise from restrictions on federal coal leasing, from the long lead times required to construct mines and to obtain operating permits, and from the large capital investments required to minimize average extraction cost. Second, mines in the PRB, both then and today, produce heterogeneous coal with important differences in BTU and in levels of impurities such as sulfur, sodium, and ash. Power engineers in the early 1980s widely believed that, because particular generating units only could accommodate coal with narrowly defined characteristics, the heterogeneity of PRB coal deposits limited substitution possibilities between suppliers. This provided an incentive for both mines and utilities to enter into longterm contracts to protect relationship-specific investments (Joskow 1987). Third, railroads may have market power because few railroads serve PRB mines and alternative modes of coal transportation out of the PRB either are not cost-effective (e.g., trucking) or else do not exist (e.g., barges and coal slurry pipelines). 
Fourth, as Kolstad and Wolak (1983) observe, state governments may exert market power by competing strategically for resource rents through severance taxes on production.

Since these early studies, new information has come to light to suggest that much has changed in the coal market. Barriers to entry eased substantially following the procoal decision of the U.S. Supreme Court in Sierra Club v. Kleppe in 1976 and the end of the moratorium on federal coal leasing in the 1980s. Between 1984 and 2002, the number of operating mines remained constant (twenty mines), while average annual production per mine grew from 6.1 million tons to 18.75 million tons, which suggests that mines today exploit economies of scale to a greater extent than they did in earlier years. Average production costs for PRB coal declined sharply over this period as a result of capital investment in excavation equipment such as conveyors, earth-moving vehicles, and draglines together with advances in computerization and control equipment (Darmstadter 1999). A production-weighted average of engineering estimates of mine-specific real variable costs per ton declined by $57 \%$ between 1985 and 2000 (\$4.68/ton vs. $\$ 2.01 /$ ton). Indeed, even in nominal terms, the average extraction costs for PRB coal declined by nearly $40 \%$ (BXG, Inc. 1985a; Hill and Associates, Inc. 2000). ${ }^{3}$ Accordingly, the average real minemouth price of PRB coal fell by $64 \%$ (from $\$ 13.97 /$ ton vs. \$5.38/ton) (U.S. Department of Energy, Energy Information Administration various years) over the period.

The decline in coal production costs and mine-mouth prices in the PRB, mirrors a nationwide trend in coal markets. For instance, in the Illinois Basin, an important high-sulfur coal region, a production-weighted average of engineering estimates of mine-specific real variable costs per ton fell by about the same percentage as in the PRB between 1985 and 2002 (54\%; \$32.09/ton vs. \$14.62/ton) (BXG, Inc. 1985b; Hill and Associates, Inc. 2003) and real mine-mouth prices declined by about $26 \%$ from $\$ 37.36 /$ ton to $\$ 21.43 /$ ton over the period 1985-2000 (U.S. Department of Energy, Energy Information Administration various years).

PRB coals now are generally viewed as good, though not perfect, substitutes with each other and with eastern coals in the generation

\footnotetext{
${ }^{3}$ All real values in this article are expressed in year 2000 dollars and are obtained using the GDP deflator.
}

of electric power for two reasons. First, power plants generally have different types of generating units engineered to burn different fuels and can use each unit more or less intensively as relative fuel prices and government regulations change. Second, coals obtained from different PRB mines are now commonly mixed with each other in an increasingly diversified fuel portfolio and, coincident with the passage of the Clean Air Act Amendments of 1990, blending of PRB coal with eastern coals began in the early 1990s. ${ }^{4}$ In 1999, for example, $73 \%$ of plants that bought PRB coal did so from more than one mine, and, at each plant, the PRB coal purchased was sourced (on average) from 2.75 mines.

Partly as a result of the increased potential for fuel mixing, long-term contracts (e.g., twenty years) diminished in importance throughout the 1990 s. $^{5}$ Today, spot market purchases combined with sales under shorter-term contracts of four years or less represent the industry norm. Current PRB coal contracts almost uniformly contain market based reopener provisions in place of price escalation or take-or-pay requirements, and this increases the exposure of both mines and utilities to market forces.

Evidence from the last twenty years also suggests a limited scope for strategic behavior by state governments in the PRB. Over the period 1980-2000, Wyoming coal production more than tripled from 94 million tons to 340 million tons, while Montana coal production increased only slightly from 30 million tons to 38 million tons (U.S. Department of Energy, Energy Information Administration 2003). At least three factors appear to explain the differing fortunes of the coal industry in the two states: (1) largely because of lower in situ ratios (bank cubic yards of overburden moved per ton of recoverable coal), coal production costs have remained substantially lower in Wyoming

\footnotetext{
${ }^{4}$ Perhaps $25 \%$ of coal-fired generating units now burn a blend of PRB and eastern coal. Nevertheless, to blend these two types of coal requires a significant capital cost and certain technical barriers must be overcome. PRB coal, which is subject to spontaneous combustion, has roughly $70 \%$ of the BTU content per pound as compared with Illinois Basin coal. This means that as more PRB coal is added to the blend, a greater total volume of coal is needed to generate a fixed amount of energy, more ash must be disposed of, and more maintenance must be performed on coal handling and generating equipment. A separate storage area for PRB coal also is needed along with additional space and equipment to mix it with other coals. Because of the large capital cost that would be incurred, completely switching a generating unit's fuel source between types of coal remains uncommon.

${ }^{5}$ The expiration of long-term contracts and the concomitant shift to spot sales and short-term sales agreements represents another reason for the decline in $\mathrm{PRB}$ coal prices mentioned previously.
} 
than in Montana; ${ }^{6}$ (2) Wyoming coal is generally of higher quality and contains fewer impurities than Montana coals $;^{7}$ and (3) the transportation infrastructure out of Wyoming is better developed than its counterpart out of Montana, a feature undoubtedly related to the differences noted above in the extraction cost and quality of deposits. For these reasons, strategic behavior among state governments is suppressed and the empirical analysis in the article focuses on Wyoming PRB coal production.

Prior evidence also suggests that railroads exert market power. Wolak and Kolstad (1988) examine market power in the Western U.S. coal market and conclude that railroads hauling coal, and in particular railroads hauling coal out of Wyoming, exercise market power. Among railroads serving Wyoming, two lines-Burlington Northern Santa Fe (BNSF) and Union Pacific (UP) - currently initiate all transportation of PRB coal. ${ }^{8}$ These railroads generally employ trains of 100 cars or more to haul coal from Wyoming mines to either individual electric power plants or terminals, and the rail cars, which do not simultaneously carry other commodities, subsequently return empty to the mines.

\section{Model}

The model extends the framework of Greenhut and Ohta (1972) to consider spatial market power in a duopoly railroad sector with an endogenously determined service region. Each railroad purchases low-sulfur coal at spot prices from a competitive mining industry in the PRB and delivers it to a series of spatially distributed, but otherwise identical electricity generating units (utilities). The railroads deliver only a single product-PRB coal—and select freight schedules over distance as well as a terminal point that defines the geographic extent of the market. Attention is limited to cases in which economies of scope do not exist

\footnotetext{
${ }^{6}$ In 2000, a production-weighted average of engineering estimates of mine-specific variable costs per ton was $67 \%$ higher in Montana than in Wyoming, a percentage cost difference approximately identical to that which prevailed in 1985 (BXG 1985a; Hill and Associates 2000).

${ }^{7}$ For example, among the so-called "super-compliance" coals (those with very low $\mathrm{SO}_{2}$ per million BTU), the high sodium content of Montana deposits limits their marketability.

${ }^{8}$ The Chicago and Northwestern Railroad, which entered the Wyoming coal transportation market in the early 1980s, no longer serves the PRB. Also, the BNSF and UP do not always complete deliveries to all power plants because coal is frequently transshipped via other lines.
}

in the transportation cost function. The reason is that deliveries of PRB coal are sufficiently large that each delivery involves a separate trip between a PRB mine and a utility.

The spatial dimension of the market is described by railroad shipments between mineutility pairs, where a mine-utility pair is measured as the distance between a utility and its source mine for PRB coal. To focus attention on railroad behavior, the source mines for PRB coal are consolidated at a single point in space (the origin) and utility location is measured continuously in terms of distance from the origin along a rail line of unit length. ${ }^{9}$ The maximum distance shipped by the railroads, $N^{*} \in(0,1)$, defines the service region for lowsulfur coal, and the remaining utilities, those located on the segment $1-N^{*}$, burn high-sulfur coal.

Individual electric generating units ("boilers") are assumed to be identical across utilities, so that the agglomeration of boiler units into power plants at various points in space is subsumed into the spatial distribution of utilities. Because the freight rate on any route is independent of the freight rate on any other route, moreover, it is not necessary to specify the distribution of utilities along the rail line, except when considering the total quantity of coal delivered. For illustrative purposes, the effect of $\mathrm{SO}_{2}$ policy on aggregate $\mathrm{PRB}$ coal shipments is computed under the assumption of a uniform distribution of utilities, although the results readily generalize to the case of any known distribution.

\section{Utility Demand for PRB Coal}

The fuel portfolio available to utilities is comprised of low-sulfur PRB coal and high-sulfur coal. All sources of high-sulfur coal are assumed to have identical sulfur content, and the sources are sufficiently numerous that the delivered price of high-sulfur coal is invariant over space. ${ }^{10}$ By confining attention to only two sources of fuel, the model focuses on the empirical regularity of expanding PRB coal markets into high-sulfur coal regions in the Midwest, while suppressing the possibility that utilities may choose to burn fuels

\footnotetext{
${ }^{9}$ Greenhut and Ohta (1972) consider a discrete (and exogenous) number of consumers evenly distributed along a line. The specification here of a continuous distribution facilitates the calculation of an endogenous service region.

${ }^{10}$ In the predominant region of interest-the Midwest-power plants generally have several nearby alternatives for high-sulfur coal.
} 
other than coal, such as natural gas, or avoid fuel-switching altogether by installing postcombustion abatement equipment ("scrubbers"). ${ }^{11}$ Switching from high-sulfur coal to low-sulfur coal is an attractive compliance option for many utilities, and to highlight this choice, low-sulfur coal is treated as a pollutionfree alternative to high-sulfur coal.

The electricity market is assumed to be competitive and the boiler units used by utilities are homogeneous in all respects apart from their location in space. Let $p_{e}$ denote the electricity price, and let $p_{l}(x)$ and $p_{h}$ denote, respectively, the delivered prices of PRB coal and high-sulfur coal to a utility at distance $x$.

Utilities are arrayed spatially along the rail line and face different freight rates, and hence different delivered prices, for PRB coal. To see the implication of this for fuel-switching behavior, suppose $p(x)$ rises smoothly from zero over distance. Rising prices over distance divide utilities into three possible categories: $(i)$ for plants sufficiently close to the PRB source mines, delivered prices of PRB coal are low enough relative to the high-sulfur coal price that only PRB coal is used; (ii) for plants at an intermediate range of distances, delivered prices of PRB coal are such that fuel mixing between PRB coal and high-sulfur coal occurs; and (iii) for sufficiently long distances, delivered prices of PRB coal are high enough that utilities buy only high-sulfur coal.

The goal of the model is to examine the effects of changes in environmental policy, transportation cost $(t)$ and the mine price $(w)$ on the quantity of low-sulfur sold coal in the market and on the maximum distance it is shipped. These outcomes are largely determined by railroad pricing behavior on the extensive margin where fuel switching occurs. To clarify these effects, the remainder of this section treats highand low-sulfur PRB coal as perfect substitutes in the generation of electricity. While this is a strong assumption, it has the advantage of creating a clear separation between the intensive margin and the extensive margin of railroad service by suppressing the intermediate region where fuel mixing occurs. It also facilitates the interpretation of the econometric estimates presented in the next section. Implications of relaxing the perfectly substitutable fuels assumption are noted later on.

The problem facing a utility at distance $x$ is to select the quantity of PRB coal, $q_{l}(x)$, and

\footnotetext{
${ }^{11}$ Fuel-switching has proven to be a considerably more effective method of emissions control than postcombustion abatement technology. See Carlson et al. (2000).
}

high-sulfur coal, $q_{h}(x)$, to maximize profits subject to environmental policy on $\mathrm{SO}_{2}$ emissions. Let $\sigma$ denote the $\mathrm{SO}_{2}$ emissions coefficient for high-sulfur coal, so that $\mathrm{SO}_{2}$ emissions for a utility at distance $x$ can be defined as $e(x)=$ $\sigma q_{h}(x)$. Each utility is given an initial endowment of $\mathrm{SO}_{2}$ allowances and must purchase an $\mathrm{SO}_{2}$ allowance for each unit of emissions above this level at a price of $\lambda$.

The market price of an $\mathrm{SO}_{2}$ allowance $(\lambda)$ is taken as given by each firm, but is determined endogenously by the cap on total emissions in the market. Total $\mathrm{SO}_{2}$ emissions are given by $E=\sigma \int_{0}^{1} q_{h}(x) d x$, and the sum of all $\mathrm{SO}_{2}$ allowances must meet the regulated level of $E$ under the emissions cap.

A utility with an initial endowment of $e_{0}$ allowances maximizes profits of

$$
\begin{aligned}
\pi^{u}(x)= & p_{e} f\left(q(x)+q_{h}(x)\right)-p(x) q_{l}(x) \\
& -p_{h} q_{h}(x)+\lambda\left(e_{0}-e(x)\right)
\end{aligned}
$$

subject to nonnegativity constraints on the use of low-sulfur coal, $q_{l}(x) \geq 0$ and high-sulfur coal $q_{h}(x) \geq 0$, and the relationship between high-sulfur coal use and $\mathrm{SO}_{2}$ emissions, $e(x)=$ $\sigma q_{h}(x)$.

The first-order necessary conditions for a maximum are

$$
\Gamma_{l} \equiv p_{e} f^{\prime}(.)-p_{l}(x) \leq 0 \quad \Gamma_{l} q_{l}(x)=0
$$

$$
\Gamma_{h} \equiv p_{e} f^{\prime}(.)-p_{h}-\sigma \lambda \leq 0, \quad \Gamma_{h} q_{h}(x)=0
$$

where $f^{\prime}($.$) denotes the marginal product of$ coal in electricity production. Let $p_{s}=p_{h}+$ $\sigma \lambda$ denote the effective price of high-sulfur fuel (inclusive of the permit requirement). Notice that the effective price of high-sulfur coal is independent of distance; hence the choice of a utility to burn PRB coal or high-sulfur coal depends only on the relative prices, $p_{l}(x)$ and $p_{s}$. By inspection of expressions (1) and (2), the conditional (inverse) demand for low-sulfur coal is given by $p(x)$ for $p(x) \leq p_{s}$ and zero otherwise.

\section{The Rail Sector}

In the upstream market, the spot price per unit of coal at the mine mouth is $w .{ }^{12}$ In the transportation sector, the marginal cost of hauling

\footnotetext{
${ }^{12}$ Note that this formulation sets aside issues of scarcity and increasing "user cost." Low-sulfur PRB coal is in abundant supply and, as noted in the previous section, mine-mouth prices have trended downward over time.
} 
one unit of coal an additional unit of distance is $t .^{13}$ Accordingly, the total cost of delivering the quantity, $q_{l}(x)$, to a utility at distance $x$, is $\operatorname{txq}_{l}(x)$, and the total cost of procuring and hauling coal is $c(Q)=\int_{0}^{N}(w+t x) q_{l}(x) d x$, where $N$ is the extensive margin of service. Fixed costs, which are necessary to justify the existence of railroad market power, play no role in the analysis and are consequently omitted.

The railroad's problem is to select the number of utilities to serve, $N^{*}$, and a delivered quantity for each utility in the service region $x \in\left[0, N^{*}\right]$. The freight charge per unit of coal delivered to a utility at distance $x$ is defined as the difference between the delivered price and the mine price, $f(x)=p\left(q_{l}(x)\right)-w$.

Railroads hauling low-sulfur coal compete in a homogeneous product transportation market subject to capacity constraints on the available rail cars. Because this capacity must be allocated across all routes, the outcome for PRB freight prices can range from competitive to monopolistic (i.e., railroad collusion), depending on the intensity of competition between the railroads along individual routes. Busse and Keohane (2007) describe this outcome as a series of bargaining problems between a monopoly railroad and utilities over freight rates, an approach that is conceptually equivalent to introducing distancespecific conduct parameters to describe the departure from marginal cost pricing along each route. Their approach is to examine whether the Table A designation of electric plants leads to systematic differences in the bargaining outcome, whereas the approach taken here is to characterize the spatial market equilibrium under railroad competition and railroad monopoly, respectively, with regard to minemouth prices, transportation costs, and the introduction of $\mathrm{SO}_{2}$ policy.

Under competition with constant unit transportation costs, the freight schedule, $f^{c}(x)=t x$, rises linearly from zero at a rate of $t$ over distance to maintain the delivered PRB coal price equal to marginal transportation cost, $p(x)=$ $w+t x$. The competitive service region for PRB coal terminates at distance $N^{*}$ when the delivered price rises to $p_{s}=w+t N^{*}$.

Under monopoly, demand is assumed to be downward sloping, differentiable, and to satisfy

\footnotetext{
${ }^{13}$ This assumption of constant marginal cost per ton-mile is corroborated by empirical analysis later on.
}

$$
p^{\prime}\left(q_{l}(x)\right)+q_{l}(x) p^{\prime \prime}\left(q_{l}(x)\right)<0 .
$$

Equation (3), which always holds for linear and concave demand, is related to the standard existence condition under oligopoly (see, e.g., Novshek 1985). Its role is to guarantee that marginal revenue declines faster than price as the delivered quantity increases, which implies that demand is more elastic at higher prices. The transversality condition derived below requires demand to be infinitely elastic at the extensive margin of service, and this occurs naturally over distance by condition (3) as transportation costs (and delivered prices) rise.

The optimal freight schedule potentially has two distinct spatial regions, which are referred to as region I and region II. In region I, utilities purchase a sufficiently large quantity of PRB coal that interior monopoly prices obtain, $p\left(q_{l}(x)\right)<p_{s}$. In region II, utilities are sufficiently distant that the unconstrained monopoly price exceeds the price of highsulfur coal. The railroads may continue to serve utilities in this region, but can do so only under the binding constraint that $p\left(q_{l}(x)\right)=p_{s}$. This implicitly defines a unique quantity delivered to each region II utility, denoted hereafter by $q_{l}^{s}$.

Let $n$ denote the number of region I utilities served, and $m=N-n$ denote the number of region II utilities served. The total quantity of coal shipped by the railroads is

$$
Q_{l}(x)=\int_{0}^{n} q_{l}(x) d x+m q_{l}^{s}
$$

and railroad profit, accordingly, is

$$
\begin{aligned}
\pi\left(w, t, p_{s}\right)= & \int_{0}^{n}\left(p\left(q_{l}(x)\right)-t x-w\right) q_{l}(x) d x \\
& +\int_{n}^{N}\left(p_{s}-t x-w\right) q_{l}^{s} d x .
\end{aligned}
$$

The first-order necessary conditions for a maximum profit are given by the Euler equation,

$$
\begin{array}{r}
p\left(q_{l}(x)\right)+q_{l}(x) p^{\prime}\left(q_{l}(x)\right)-t x-w=0, \\
\text { for } x \in[0, n]
\end{array}
$$

the region I boundary condition,

$$
p\left(q_{l}(n)\right)=p_{s}
$$

and the transversality condition, 


$$
\left(p_{s}-t N-w\right) q_{l}^{s}=0
$$

where the substitution $p\left(q_{l}(N)\right)=p_{s}$ has been made in equation (7). ${ }^{14}$ Equations (5)-(7) have a straightforward interpretation. Equation (5) is the condition for optimal spatial pricing in region I. This is the standard monopoly pricing condition that marginal revenue be set equal to delivered marginal cost $(w+t x)$ for PRB coal deliveries to the utility at distance $x$. Equation (6) defines the point in distance $\left(x=n^{*}\right)$ where the monopoly price of delivered PRB coal equates with the price of the alternative fuel, which describes the region I boundary. At distance $n^{*}$, the unconstrained monopoly price rises to $p_{s}$ and further price increases are not feasible; however, profit is still positive for shipments at this distance. Equation (7) defines the extensive region of railroad service (the region II boundary). Deliveries continue to the distance $N^{*}$, where $p_{s}$ equates with marginal transportation cost and profit is zero.

Let $q_{l}^{*}(x, t, w), n^{*}\left(t, w, p_{s}\right)$, and $N^{*}\left(t, w, p_{s}\right)$ denote the solutions to (5)-(7). The railroad freight rate schedule is

$$
\begin{aligned}
& f^{*}\left(x, t, w, p_{s}\right) \\
& =\left\{\begin{array}{cc}
p\left(q_{l}^{*}(x, t, w)\right)-w & \text { for } x \leq n^{*}\left(t, w, p_{s}\right) \\
p_{s}-w & \text { for } x>n^{*}\left(t, w, p_{s}\right) .
\end{array}\right.
\end{aligned}
$$

The freight rate schedule (8) rises over distance in region I until the distance $n^{*}\left(t, w, p_{s}\right)$ is reached, beyond which point freight rates remain constant over distance in region II until the terminal distance where the freight rate equates with transit cost, $p_{s}-w=t N^{*}\left(t, w, p_{s}\right)$. Thus, in region II the relative price of highsulfur coal (gross of permits) to the delivered price of PRB coal must equate to unity.

The freight rate schedules under competition and monopoly are depicted in figure 1 for the case of linear demand. Notice that a competitive railroad industry does not have a region II portion of the freight rate schedule, whereas a monopoly (and oligopoly) railroad does. The monopoly freight rate schedule is piecewise concave, exhibiting a positive markup at the origin $(x=0)$, rising at a more gradual rate than under competition throughout region I (e.g., at rate $t / 2$ when demand is linear), and then equating with $p_{s}-w$ in

\footnotetext{
14 The Legendre condition associated with profit maximization holds strictly by condition (3).
}

region II. ${ }^{15}$ Notice that the number of utilities served, $N^{*}$, which is determined by the zero profit condition (7) at the extensive margin of service, is independent of railroad market structure. Nevertheless, because freight rates are lower throughout the service territory under competition (and identical only for the utility at distance $N^{*}$ ), a competitive railroad industry delivers a greater total quantity of PRB coal.

Let $\phi(x)=f(x) / x$ denote the freight rate per ton-mile. In a competitive railroad sector, the freight rate per ton mile is constant, $\phi^{c}(x)=t$. Under monopoly, the freight rate per ton mile decreases over distance, because of the ability of railroads to spatially price discriminate. Unit delivery cost rises at a constant rate of $t$ per unit of distance, but the margin between delivered price and unit cost falls as demand becomes increasingly elastic at more distant utilities. Market power declines over distance for a monopoly railroad in both service regions.

\section{Testable Predictions}

Two types of predictions can be derived from the model: $(i)$ comparative static effects of changes in mine-mouth PRB prices, $w$, and railroad transportations costs, $t$, on the railroad service region and, on freight rates, and (ii) the effect of changes in $\mathrm{SO}_{2}$ policy. These predictions are presented in turn below and are then empirically tested in the following section.

Equation (7) indicates that the extent of the railroad service region, $N^{*}$, does not depend on market structure. Therefore, cost innovations that reduce either $w$ or $t$ have an expansionary effect on the market area for PRB coal that is independent of the degree of railroad market power.

Within the service territory for PRB coal, the freight rate under competition, $f^{c}(x)=t x$, does not respond to changes in $w$, and a small decrease in transportation costs of $d t$ units decreases the freight rate per ton by $x d t$ units. Under monopoly, a one-unit reduction in $w$ reduces the delivered price to each utility in region I and extends the region I boundary (i.e., $n^{*}$ increases in figure 1). Freight rates rise by less than one unit to utilities in region I, whereas freight rates rise by exactly one unit to utilities in region II. A decline in transportation costs lowers freight rates to region

\footnotetext{
${ }^{15}$ In the case where low- and high-sulfur coal are imperfect substitutes and fuel mixing occurs along the entire rail line, the monopoly freight schedule is smoothly concave.
} 


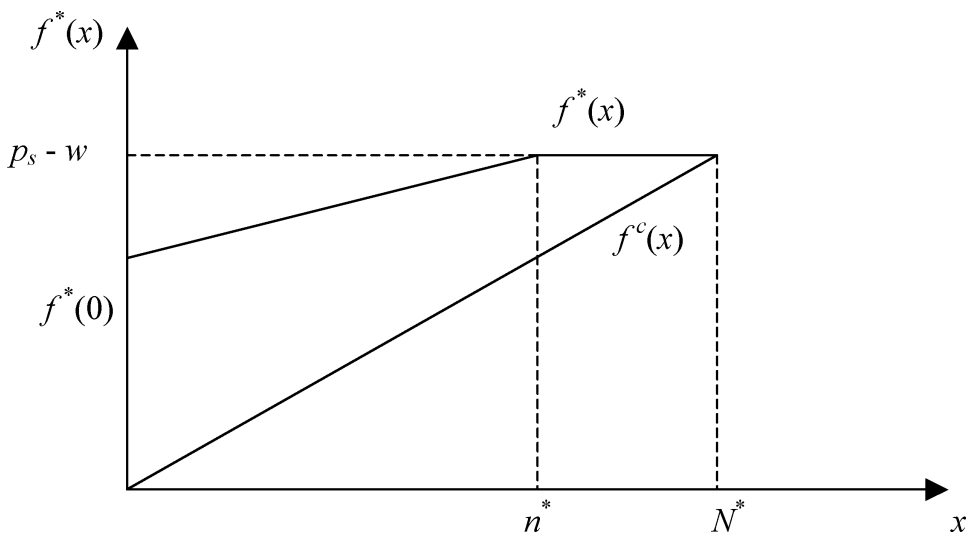

Figure 1. Freight rate per ton schedules over distance under competition and oligopoly

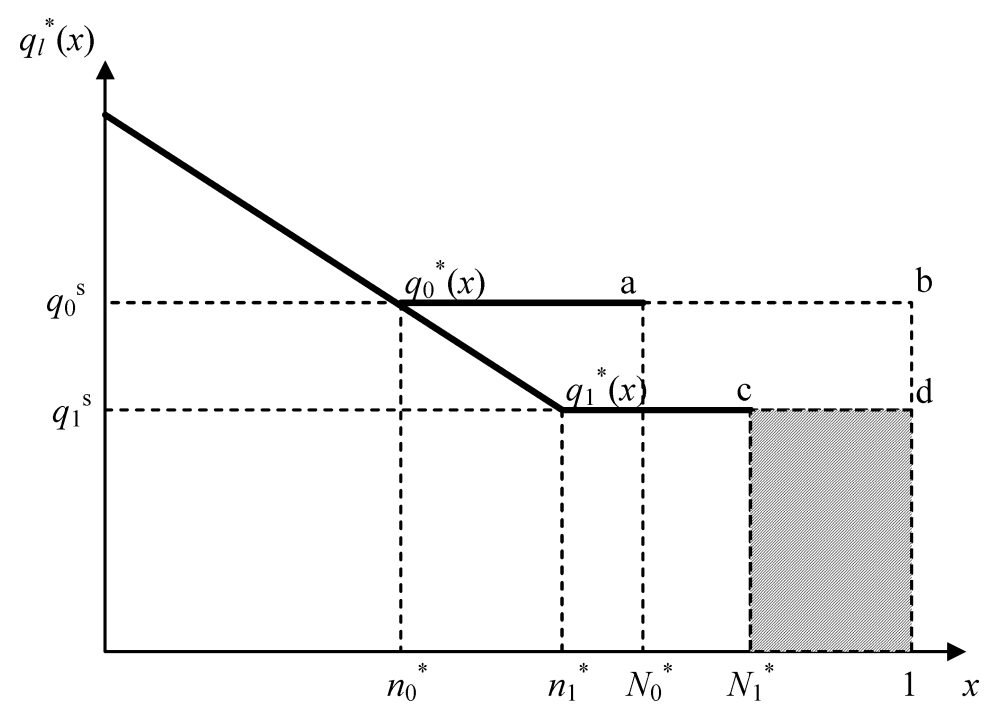

Figure 2. Total quantity of PRB coal delivered under monopoly freight pricing

I utilities and expands the region I boundary. A transportation cost decrease of $d t$ units decreases monopoly freight rates by less than $x d t$ units in region $\mathrm{I}$, but has no effect on freight rates in region II because demand for PRB coal at these plants is perfectly elastic (see figure 1).

A tradable allowance system for $\mathrm{SO}_{2}$ emissions introduces a market price to reflect the $\mathrm{SO}_{2}$ content of high-sulfur coal. The requirement that utilities purchase $\mathrm{SO}_{2}$ allowances to offset their emissions increases the effective price of high-sulfur coal from $p_{h}$ to $p_{s}=$ $p_{h}+\sigma \lambda$ (see equation (2)). The $\mathrm{SO}_{2}$ allowance price $(\lambda)$ that emerges in the permit market is determined by the magnitude of the mandated reduction in $\mathrm{SO}_{2}$ emissions - the size of the "cap"- and by the market demand for allowances. Given the spatial distribution of util- ities burning PRB coal and high-sulfur coal, market demand for $\mathrm{SO}_{2}$ allowances is defined by aggregate demand for coal at electric plants located at distances $\left(1-N^{*}\right)$ along the rail line. Policies that limit the aggregate quantity of $\mathrm{SO}_{2}$ emissions alter both the extensive margin of service for PRB coal and the quantity of high-sulfur coal burned at each utility outside the service region for PRB coal. ${ }^{16}$

The effect of $\mathrm{SO}_{2}$ regulation on the spatial distribution of PRB coal deliveries is depicted in figure 2. Figure 2 shows the delivered

\footnotetext{
${ }^{16}$ An alternative to fuel substitution among utilities burning highsulfur coal is to meet the emissions cap by changing the emissions coefficient $(\sigma)$, for instance by installing postcombustion abatement technology. These effects are suppressed for the reasons discussed earlier.
} 
quantity schedule over distance for the case of linear utility demand for coal. Prior to environmental regulation, the delivered quantity schedule declines over distance at rate $-t / 2 p^{\prime}$ in region I (see equation (5)), and then remains constant thereafter at $q_{0}^{s}$ in region II. Region I extends outward from the source mines to the distance $n_{0}^{*}$ and the length $N_{0}^{*}-n_{0}^{*}$ defines the extent of region II. The total delivered quantity of PRB coal is the area under the quantity schedule $q_{0}\left(x^{*}\right)$. The total quantity of highsulfur coal burned by electric utilities sums the quantity of coal demanded by utilities located at distances $1-N_{0}^{*}$. Because each plant outside the PRB service territory burns $q_{0}^{s}$ units of coal, the total quantity of high-sulfur coal used by all plants is $\left(1-N_{0}^{*}\right) q_{0}^{s}$, which is represented in the figure by the area $N_{0}^{*} a b 1$. Prior to $\mathrm{SO}_{2}$ regulation, total emissions are $E_{0}^{*}=$ $\sigma\left(1-N_{0}^{*}\right) q_{0}^{s}$.

After cap-and-trade regulation, total $\mathrm{SO}_{2}$ emissions decrease to the regulated level, $E_{1}^{*}=$ $\sigma\left(1-N_{1}^{*}\right) q_{1}^{s}<E_{0}^{*}$. The decrease in industry $\mathrm{SO}_{2}$ emissions occurs through a combination of input price effects that reduce the use of high-sulfur coal by utilities, $q_{1}^{s}<q_{0}^{s}$, and fuel substitution effects from high-sulfur coal to PRB coal among utilities on the extensive margin of service, $N_{1}^{*}>N_{0}^{*}$. For an arbitrary emissions cap of $E_{1}$ units, the total amount of highsulfur coal used in the regulated industry is represented in figure 2 by the shaded region, area $N_{1}^{*} c d 1$, for the case of $\mathrm{SO}_{2}$ regulation that limits the total quantity of high-sulfur coal burned at electric utilities to $\left(1-N_{1}^{*}\right) q_{1}^{s}$. Utilities located at distances between $N_{0}^{*}$ and $N_{1}^{*}$ comply with the regulation by substituting away from high-sulfur coal to PRB coal and selling their $\mathrm{SO}_{2}$ allowances to utilities located at greater distances from the source mines for PRB coal. The outward expansion of the service region for PRB coal drives up the delivered price of PRB coal (see equation (7)), and the expansion of the PRB service territory continues to distance $N_{1}^{*}$ where the zero profit condition on the extensive margin of the railroad service region clears individual input demand for the remaining $1-N_{1}^{*}$ utilities at the quantity $\left(q_{1}^{s}\right)$ necessary to clear the emissions market at $E_{1}^{*}$ units. ${ }^{17}$ For a binding emissions cap, the equilibrium allowance price solves equation (7): $\lambda^{*}=\left(t N_{1}^{*}+\right.$ $\left.w-p_{h}\right) / \sigma$.

\footnotetext{
${ }^{17}$ Formally, under an emissions cap of $E_{1}^{*}$ units the extensive margin of PRB service must satisfy $N_{1}=1-E_{1}^{*} / \sigma q_{1}$, which can be used together with equations (6) and (7) to recover $q_{1}^{s}$ and $N_{1}^{*}=1$ $-E_{1}^{*} / \sigma q_{1}^{s}$.
}

The permit price that emerges in the $\mathrm{SO}_{2}$ allowance market is independent of market structure in the PRB transportation sector. The reason is that the permit price is driven by fuel switching behavior at the extensive margin of railroad service (region II) and utility demand for PRB coal is perfectly elastic for these utilities. The quantity of high-sulfur coal purchased by each utility located in the region $1-N_{1}^{*}$ must clear the individual input demand at a level $\left(q_{1}^{s}\right)$ that exactly allocates aggregate $\mathrm{SO}_{2}$ emissions to meet the cap, and the effective price of high-sulfur coal, $p_{s}$, must rise to clear the demand at this quantity. ${ }^{18}$

Within the service territory for PRB coal, $\mathrm{SO}_{2}$ policy has no effect on freight rates for incumbent region I utilities. Under railroad competition, freight rates for delivery of PRB coal are not altered for existing subscribers and the service territory for PRB coal expands until transportation costs rise to equate the delivered price of PRB coal with the permitinclusive price of high-sulfur coal at $N_{1}^{*}$. Utilities switching away from high-sulfur coal and to PRB coal as a result of $\mathrm{SO}_{2}$ regulation (i.e., utilities located at distances between $N_{0}^{*}$ and $N_{1}^{*}$ ) pay higher freight rates than incumbent PRB subscribers, although the competitive freight rate per ton mile $(t)$ remains constant for all utilities. Under railroad monopoly, freight rates remain constant for incumbent region I utilities following $\mathrm{SO}_{2}$ regulation, but freight rates rise for both incumbent and entrant utilities in region II. Utilities located at distances between $N_{0}^{*}$ and $N_{1}^{*}$ that enter the PRB service territory in response to $\mathrm{SO}_{2}$ regulation pay the same delivered price for PRB coal as incumbent region II utilities located at distances between $n_{1}^{*}$ and $N_{0}^{*}$.

\section{Empirical Analysis}

This section describes the data used in the empirical analysis, presents econometric results, and uses these results to test various implications of the model.

\footnotetext{
${ }^{18}$ Differences in $\mathrm{SO}_{2}$ allowance prices would emerge under various railroad market structures due to indirect effects of the policy on consumer energy prices that are suppressed in the present model by treating energy prices as constant in equations (1) and (2). With downward-sloping energy demand, $\mathrm{SO}_{2}$ policy reduces the total amount of coal combusted by electric utilities, which increases consumer energy prices and shifts the derived demand for coal outward at each utility, and the level effect of the shift in coal input demand at the quantity level $q_{1}^{s}$ would be capitalized into $\mathrm{SO}_{2}$ allowance prices.
} 


\section{Data}

Data on railroad costs and freight rates are taken from the 1988-1999 Carload Waybill Samples of the U.S. Department of Transportation, Surface Transportation Board (STB). These data are not generally available, but are provided when officially requested for a state-oriented research project by that state's government. Data consist of a sample of railroad shipments either originating, terminating, or passing through Wyoming. For each year, the data were filtered to eliminate all non-coal shipments, and coal shipments of fewer than fifty cars, where the latter filter was applied to eliminate intermittent coal shipments (i.e., for test burns). Each year, the filtered data represent between 35 and $45 \%$ of total Wyoming coal shipments.

The filtered data on individual coal shipments were aggregated to yield 1229 observations on annual coal shipments by route (i.e., from one of sixteen railheads to one of eighty-seven power plants) for the period 1988-1999. ${ }^{19}$ The data form an unbalanced panel, as deliveries of PRB coal were made to an increasing number of power plants over time. For example, there are fifty-five routes with at least one shipment in the 1988 sample and 150 routes with at least one shipment in the 1999 sample. In the entire sample, there are 353 routes along which deliveries were made. The main data elements for each route in each year consist of total variable costs, total freight revenue, total tonnage of sampled shipments, and route length (in railroad miles).

While the Carload Waybill Sample data contain detailed measures of railroad costs and freight rates that are otherwise unavailable, they are not without limitations. Variable costs are not measured directly, but rather are imputed using national relationships for forty class I railroads for each year. Also, exact freight revenue data are confidential and approximate (sometimes overstated) values are reported for some shipments (for further details, see Association of American Railroads 2000).

Available data for real variable transportation cost per ton-mile and real freight rates

\footnotetext{
${ }^{19}$ Aggregation of individual shipments is necessary to comply with STB disclosure rules. These rules require data to be aggregated to the level of at least three shippers to prevent the identification of individual railroads (Code of Federal Regulations 2001). As indicated previously, two railroads initiated all shipments of Wyoming PRB coal, but because of transshipments to other lines, a total of sixteen railroads were involved delivering coal to power plants along the sample routes.
}

per ton-mile indicate that both variables decline over time. Over the sample period, real variable cost declined by $36 \%$ from an average of 11.47 mills per ton-mile across all routes in 1988 to 7.34 mills per ton-mile across all routes in 1999 and real freight rates per ton-mile declined by $36 \%$ from an average of 19.65 mills per ton-mile across all routes in 1988 to an average of 12.58 mills per ton-mile across all routes in 1999. Under difference between means tests, the declines in both variables are statistically significant at $1 \%$.

Further analysis of the cost data suggests that marginal transportation cost per ton-mile is roughly constant with respect to both tons and distance, a result that is established by regressing the natural logarithm of total real railroad variable cost on the natural logarithm of ton-miles with fixed effects for each of the 353 routes and for each of the eleven years $(\mathrm{n}=1,229)$. The estimated elasticity of total variable cost with respect to ton-miles is 0.986 $($ s.e. $=0.003)$. Thus, marginal cost per ton-mile is approximately equal to average variable cost per ton-mile and both marginal cost and average cost are constant over tonnage and distance, a plausible outcome because trains hauling coal from the PRB do not carry other commodities that would require stops at multiple delivery points.

Table 1 shows the behavior of real freight rates per ton-mile by computing Lerner indices over routes of different length. Lerner indices for each route in each year were obtained by expressing the difference between the freight rate per ton-mile and marginal (= average) cost per ton-mile as a percentage of the freight rate per ton-mile. Values in table 1, obtained by averaging within each of three distance categories, show that the Lerner indices decline significantly (at $1 \%$ ) with distance, suggesting that railroads exercise market power. ${ }^{20}$ While not shown in Table 1, Lerner indices also declined across all routes by an average of $15 \%$ between 1988 and 1999. Deregulation of railroads (see Ellerman and Montero 1998 and Ellerman et al. 2000) may have played a role here, but the decline in price of high sulfur coal also may have been an important factor (see below).

In the econometric analysis, the Carload Waybill Sample data were supplemented with information taken from Form 423 of

\footnotetext{
${ }^{20}$ A separate analysis of real freight rates per ton-mile also shows that this variable declines significantly at the $1 \%$ level over distance.
} 


\begin{tabular}{|c|c|c|c|c|}
\hline & $\begin{array}{l}\text { Power Plant } \\
\text { Location is: }\end{array}$ & $\begin{array}{l}\text { Less than } 550 \\
\text { Miles from } \\
\text { PRB (1) }\end{array}$ & $\begin{array}{c}\text { Between } 550 \\
\text { Miles and 1,100 Miles } \\
\text { from PRB (2) }\end{array}$ & $\begin{array}{l}\text { More than } 1,100 \\
\text { Miles from } \\
\text { PRB (3) }\end{array}$ \\
\hline \multicolumn{5}{|l|}{ Lerner Index } \\
\hline Mean & & 0.553 & 0.372 & 0.329 \\
\hline Standard error & & 0.007 & 0.005 & 0.006 \\
\hline $\mathrm{N}$ & & 127 & 536 & 573 \\
\hline Difference between means & & (1)-(2) & (1)-(3) & (2)-(3) \\
\hline t-statistic & & 21.04 & 25.38 & 5.51 \\
\hline
\end{tabular}

the Federal Energy Regulatory Commission (FERC). This form records the quantity of coal received by a power plant on each shipment (not just sampled shipments), the delivered price, the name of the mine from which the coal was shipped, whether the shipment represented a contract or spot sale, and selected characteristics of the coal shipped including BTU, sulfur, and ash content. These data were aggregated and then matched by route and year to 1229 observations obtained from the Carload Waybill Sample.

\section{Econometric Analysis}

Implications of the theoretical model are tested by estimating a three equation simultaneous equation model to explain marginal transportation cost per ton-mile, freight rates per ton-mile, and quantity of coal shipped along each route in each year. Transportation costs and freight rates are measured in real terms. Estimation is by 3 SLS with a full set of fixed effects for routes and years. Whereas the model assumed that routes differ only in length, econometric estimates control for heterogeneity among mines and power plants as well as over time. Control for route-specific effects is achieved by expressing all variables in all equations as differences from their time means. Time-specific effects are accounted for by including dummy variables for the years 1989-1999 in each equation.

The three equations are further specified as follows. First, the equation for marginal transportation cost per ton-mile $(t)$ is linear with covariates measuring two institutional factors (railcar ownership and number of interline transfers) discussed more fully below as results of estimation are described. Because marginal cost per ton-mile was found to be approximately constant over distance, the freight rate was not entered as an explanatory variable in this equation. ${ }^{21}$ Quantity of coal shipped was not entered as a covariate either because PRB coal usually is transported in units of about 100 rail cars and the number of trips from the mines to a plant should not affect marginal transport cost on any given trip. Route-specific effects were included because marginal cost per ton-mile, while approximately constant over distance for each route, differs across routes. Time-specific effects control for factors such as railroad productivity improvements, changes in fuel costs, and the gradual switch from steel railcars to lighter-weight aluminum railcars.

Second, the freight rate equation is based on the assumption of linear power plant demand for PRB coal and makes use of equation (8). This equation indicates that if railroads exercise monopoly power, the optimal freight rate per ton $\left(f^{*}\right)$ is positive at the origin, increases with distance $(x)$ at rate $t / 2$ in region I and then, beginning at $\left(x=n^{*}\right)$ is equal to difference between the substitute fuel price and the minemouth PRB coal price $(w)$ throughout region II (see figure 1). On the other hand, if railroads behave competitively, the freight rate per ton is zero at the origin and then increases with distance at the rate of $t$ throughout the entire service territory. Thus, equation (8) suggests estimating a spline function (see Greene 2003, pp. 121-122):

$$
\begin{aligned}
f_{j \mathrm{~T}}^{*}= & \beta_{0 j \mathrm{~T}}+\beta_{1} t_{j \mathrm{~T}} x_{j} \\
& +\beta_{2} d_{j \mathrm{~T}} t_{j \mathrm{~T}}\left(x_{j}-n_{j \mathrm{~T}}^{*}\right)+u_{j \mathrm{~T}} .
\end{aligned}
$$

In equation (9), $j$ indexes routes, $\mathrm{T}$ indexes years, $d_{j t}=1$ if $x_{j} \geq n_{j t}^{*}, d_{j t}=0$ if $x_{j}<n_{j t}^{*}$, and $u$ is an error term with zero mean and

\footnotetext{
${ }^{21}$ In an alternative specification of the model, the freight rate was tried as a covariate in the marginal cost equation, however, its coefficient did not differ significantly from zero at conventional levels.
} 
a conveniently specified variance that is assumed to be proportional to the square of distance along a given route. Heterogeneity across routes is expected because of: (1) differences in mine-mouth PRB coal price (due to differences in heat and impurity content) of coals loaded at PRB railheads and (2) differences in the price of high-sulfur coal and other fuels to electric power plants. Heterogeneity over time arises because of trends in coal prices affecting all Wyoming PRB mines (e.g., due to factors identified previously that led to declining mining costs), changes in environmental policy affecting coal users, prices of $\mathrm{SO}_{2}$ emission permits, and trends in prices of fuels such as high-sulfur coal, oil and natural gas that impact fuel choices by electric power plants. In consequence, equation (9) uses fixed effects to allow for differences in the intercept as well as in the boundary between region I and region II over both routes and time. ${ }^{22}$ The fixed effects allow for correlation between the purely routeand time-varying innovations and the included covariates (x), but not with the error term (u). The slope coefficient estimates from equation (9) are interpreted as conditional on the fixed effects (see Greene 2003 for details). Restrictions on equation (9) implied by the model are that: (1) under competition, $\beta_{0 j \mathrm{~T}}=\beta_{2}=0$, and $\beta_{1}=1$ for all routes and years and (2) under railroad monopoly power, when PRB coal and high-sulfur coal are perfect substitutes, $\beta_{1}=$ $1 / 2=-\beta_{2}$ and $\beta_{0 j \mathrm{~T}}>0$ for all routes and years.

Because data on PRB mine-mouth coal prices $\left(w_{j t}\right)$ by mine and over time are unavailable, a useful approach to estimation is to substitute for $n_{j t}^{*}$ and then rewrite equation (9) (see footnote \#22) as

$$
f_{j \mathrm{~T}}^{*}=\gamma_{0 j \mathrm{~T}}+\beta_{1} t_{j \mathrm{~T}} x_{j}+\beta_{2} d_{j \mathrm{~T}} t_{j \mathrm{~T}} x_{j}+u_{j \mathrm{~T}}
$$

where if $\beta_{1}=1 / 2=-\beta_{2}$, then $\gamma_{0 j \mathrm{~T}}=\left[w_{j T}+\right.$ $\left.(a / b)_{j \mathrm{~T}}\right] / 2$ if $d_{j \mathrm{~T}}=0$ and $\gamma_{0 j \mathrm{~T}}=p_{s j \mathrm{~T}}$ if $d_{j \mathrm{~T}}=$ 1. The equation to be estimated then is obtained by dividing through by $x_{j}$ to express the dependent variable as the freight rate per tonmile, to remove heteroskedasticity in $u_{j} \mathrm{~T}$, and to include the effect of distance (a pure routespecific effect) in the intercepts. $\gamma_{o j \mathrm{~T}}$ is approximated by a set of route- and time-specific

\footnotetext{
${ }^{22}$ If, except for length, routes are homogeneous, then linear power plant demand for PRB coal $(q=a-b p)$ together with monopoly power by profit-maximizing railroads implies that $n^{*}=$ $\left[2 p_{s}-w-(a / b)\right] / t$. Allowing for heterogeneity over routes and time in alternative fuel prices, in PRB mine-mouth coal prices, and in power plant demand parameter suggest that the boundary between region I and region II will vary over routes and time as well.
}

constants. Three covariates were added to complete the specification: (1) a dummy variable to indicate whether the coal was transported to a power plant with Table A units, (2) the total annual quantity of coal purchased by the power plant (in tons per mile), and (3) a dummy variable to indicate whether the coal shipped was a spot sale.

A difficult aspect of estimating equation (10), however, is to specify $d_{j t}$ so that it appropriately classifies routes either as region I routes or as region II routes. As indicated above, it is problematic to obtain reliable estimates of $n_{j t}^{*}$ and it is not fruitful to attempt to classify region I and region II routes in each year on a priori grounds. Instead, the approach taken is to assume that values of $n_{j t}^{*}$ do not differ widely either across routes or over time, so that one value of $n^{*}$ can classify routes according to whether they serve region I or region II utilities. $^{23}$ If this assumption is workable and the model correctly describes behavior, then it should be possible to find a value of $n^{*}$ such that the estimate of $\beta_{1} \approx-\beta_{2} \approx 1 / 2$.

Third, in the demand equation for PRB coal by destination power plants, the quantity of coal was expressed as a linear function of the freight rate per ton-mile, the generation capacity of the destination plant, and a dummy variable for whether the destination plant had Table A units. Quantity of coal purchased is measured in tons per mile to maintain consistency with the freight rate equation. Because the freight rate is measured in ton-miles, this specification imposes an "identical power plant" restriction in that changes in freight rates per ton have the same effect on tons of PRB coal demanded for all power plants regardless of their distance from the mines. Route-effects were included to account for differences in characteristics of power plants and in route length. Time-effects were included to account for changes in the prices of substitute fuels and changes in environmental policy that occurred through passage of the Clean Air Act Amendments of 1990.

Table 2 presents sample means of all covariates (see column (1)) and coefficient estimates in the equations for marginal transportation cost per ton-mile (see column (2)), the freight

\footnotetext{
${ }^{23}$ An unsuccessful attempt was made to check this specification after the fact that by using available data on average prices over time for high-sulfur coal and PRB coal together with estimates from the PRB coal demand equation (see footnote \#22). Calculations of the boundary between region I and region II turned out to be quite sensitive to the estimates of the route-specific intercepts in the PRB coal demand equation.
} 


\begin{tabular}{|c|c|c|c|c|}
\hline $\begin{array}{l}\text { Explanatory } \\
\text { Variable }\end{array}$ & $\begin{array}{c}\text { Sample } \\
\text { Mean } \\
\text { (Std. Dev.) }\end{array}$ & $\begin{array}{c}\text { Real Marginal } \\
\text { Cost } \\
\text { Per Ton-Mile }\end{array}$ & $\begin{array}{c}\text { Real Freight } \\
\text { Rate } \\
\text { Per Ton-Mile }\end{array}$ & $\begin{array}{c}\text { Tons per Mile } \\
\text { of PRB Coal } \\
\text { Purchased }\end{array}$ \\
\hline $\begin{aligned}= & 1 \text { if year is } 1988 ; \\
& 0 \text { otherwise }\end{aligned}$ & $\begin{array}{c}0.044 \\
(0.205)\end{array}$ & $-^{\mathrm{b}}$ & $-^{\mathrm{b}}$ & $-^{b}$ \\
\hline $\begin{aligned}= & 1 \text { if year is } 1989 ; \\
& 0 \text { otherwise }\end{aligned}$ & $\begin{array}{l}0.050 \\
(0.219)\end{array}$ & $\begin{array}{c}-0.111 \\
(0.231)\end{array}$ & $\begin{array}{r}-0.288 \\
(0.396)\end{array}$ & $\begin{array}{c}6.21 \\
(262.10)\end{array}$ \\
\hline $\begin{aligned}= & 1 \text { if year is } 1990 ; \\
& 0 \text { otherwise }\end{aligned}$ & $\begin{array}{c}0.060 \\
(0.238)\end{array}$ & $\begin{array}{c}0.115 \\
(0.229)\end{array}$ & $\begin{array}{c}-0.671 \\
(0.387)\end{array}$ & $\begin{array}{l}-96.97 \\
(262.91)\end{array}$ \\
\hline $\begin{aligned}= & 1 \text { if year is } 1991 ; \\
& 0 \text { otherwise }\end{aligned}$ & $\begin{array}{c}0.054 \\
(0.226)\end{array}$ & $\begin{array}{r}-0.753^{*} \\
(0.229)\end{array}$ & $\begin{array}{r}-1.493^{*} \\
(0.396)\end{array}$ & $\begin{array}{l}-98.29 \\
(282.43)\end{array}$ \\
\hline $\begin{aligned}= & 1 \text { if year is } 1992 ; \\
& 0 \text { otherwise }\end{aligned}$ & $\begin{array}{c}0.063 \\
(0.242)\end{array}$ & $\begin{array}{r}-1.456^{*} \\
(0.226)\end{array}$ & $\begin{array}{r}-2.024^{*} \\
(0.387)\end{array}$ & $\begin{array}{r}-654.96^{*} \\
(297.77)\end{array}$ \\
\hline $\begin{aligned}= & 1 \text { if year is } 1993 ; \\
& 0 \text { otherwise }\end{aligned}$ & $\begin{array}{c}0.057 \\
(0.231)\end{array}$ & $\begin{array}{r}-1.327^{*} \\
(0.234)\end{array}$ & $\begin{array}{r}-2.000^{*} \\
(0.404)\end{array}$ & $\begin{array}{r}-613.62^{*} \\
(308.96)\end{array}$ \\
\hline $\begin{array}{c}=1 \text { if year is } 1994 ; \\
0 \text { otherwise }\end{array}$ & 0.099 & $-2.324^{*}$ & $-2.289^{*}$ & $-1052.32^{*}$ \\
\hline $\begin{aligned} & 0 \text { otherwise } \\
= & 1 \text { if year is } 1995 ;\end{aligned}$ & $\begin{array}{c}(0.299) \\
0.104\end{array}$ & $\begin{array}{r}(0.213) \\
-2.543^{*}\end{array}$ & $\begin{array}{r}(0.376) \\
-2.144^{*}\end{array}$ & $\begin{array}{r}(308.92) \\
-1172.94^{*}\end{array}$ \\
\hline 0 otherwise & $(0.306)$ & $(0.214)$ & $(0.381)$ & $(314.22)$ \\
\hline $\begin{array}{c}=1 \text { if year is } 1996 ; \\
0 \text { otherwise }\end{array}$ & $\begin{array}{c}0.097 \\
(0.296)\end{array}$ & $\begin{array}{r}-2.200^{*} \\
(0.224)\end{array}$ & $\begin{array}{r}-2.453^{*} \\
(0.388)\end{array}$ & $\begin{array}{r}-1864.54^{*} \\
(381.65)\end{array}$ \\
\hline $\begin{array}{c}=1 \text { if year is } 1997 ; \\
0 \text { otherwise }\end{array}$ & $\begin{array}{c}0.116 \\
(0.321)\end{array}$ & $\begin{array}{r}-2.230^{*} \\
(0.226)\end{array}$ & $\begin{array}{r}-2.301^{*} \\
(0.385)\end{array}$ & $\begin{array}{r}-2264.06^{*} \\
(423.09)\end{array}$ \\
\hline$=1$ if year is 1998 & 0.133 & $-2.560^{*}$ & $-2.824^{*}$ & $-2553.34^{*}$ \\
\hline 0 otherwise & $(0.339)$ & $(0.226)$ & $(0.395)$ & (471.26) \\
\hline$=1$ if year is 1999 & 0.122 & $-3.110^{*}$ & $-3.722^{*}$ & $-3209.98^{*}$ \\
\hline 0 otherwise & $(0.328)$ & $(0.232)$ & $(0.419)$ & $(562.48)$ \\
\hline Real Marginal Cost per ton-mile & $\begin{array}{l}1.060 \\
(3.207)\end{array}$ & $ـ^{\mathrm{b}}$ & $\begin{array}{r}0.801^{*} \\
(0.141)\end{array}$ & $\ldots$ \\
\hline $\begin{array}{l}\text { Real Marginal Cost } \times \text { dummy variable } \\
\text { that equals one if distance to utility is } \\
\text { greater than } 550 \text { miles from mine; } \\
\text { zero otherwise }\end{array}$ & $\begin{array}{c}3.897 \\
(4.697)\end{array}$ & $-^{\mathrm{b}}$ & $\begin{array}{c}-0.750 \\
(0.158)\end{array}$ & $ـ^{\mathrm{b}}$ \\
\hline Fraction of spot sales & $\begin{array}{c}0.350 \\
(0.454)\end{array}$ & $-^{\mathrm{b}}$ & $\begin{array}{r}0.568^{*} \\
(0.248)\end{array}$ & $-^{\mathrm{b}}$ \\
\hline $\begin{array}{c}=1 \text { if destination utility has Table A } \\
\text { generating units; } 0 \text { otherwise }\end{array}$ & $\begin{array}{c}0.218 \\
(0.413)\end{array}$ & $-^{\mathrm{b}}$ & $\begin{array}{c}-1.013 \\
(0.889)\end{array}$ & $\begin{array}{r}-492.20 \\
(594.92)\end{array}$ \\
\hline Number of Interline Transfers & $\begin{array}{c}0.660 \\
(0.856)\end{array}$ & $\begin{array}{r}0.343^{*} \\
(0.086)\end{array}$ & $\sim^{\mathrm{b}}$ & $-^{\mathrm{b}}$ \\
\hline $\begin{array}{l}\text { Fraction of railcars not owned by a } \\
\quad \text { railroad }\end{array}$ & $\begin{array}{c}0.762 \\
(0.340)\end{array}$ & $\begin{array}{r}-2.156^{*} \\
(0.206)\end{array}$ & $-^{\mathrm{b}}$ & $-^{\mathrm{b}}$ \\
\hline Real freight rate & $\begin{array}{l}14.718 \\
(5.451)\end{array}$ & $-^{\mathrm{b}}$ & $-^{b}$ & $\begin{array}{r}-345.59^{*} \\
(67.51)\end{array}$ \\
\hline $\begin{array}{l}\text { Destination utility generation in } \\
\text { billions of KWH }\end{array}$ & $\begin{array}{c}4.248 \\
(0.248)\end{array}$ & $-^{\mathrm{b}}$ & $-^{\mathrm{b}}$ & $\begin{array}{l}3890.67^{*} \\
(594.92)\end{array}$ \\
\hline $\begin{array}{l}\text { Tons per mile of PRB coal } \\
\text { purchased }\end{array}$ & $\begin{array}{l}1342.10 \\
(2088.09)\end{array}$ & $-^{\mathrm{b}}$ & $\begin{array}{c}-0.0002 \\
(0.0003)\end{array}$ & $-^{\mathrm{b}}$ \\
\hline
\end{tabular}

Note: All monetary variables are in mills of year 2000 dollars, standard errors are in parenthesis below coefficient estimates, the letter b denotes variables not included in a regression, and an asterisk $\left({ }^{*}\right)$ denotes a coefficient that is significant at the $1 \%$ level.

rate per ton-mile (see column (3)), and tons of coal shipped per mile (see column (4)). In the estimated equation for marginal transportation costs per ton-mile, coefficients of time dummies reflect generally decreasing marginal cost per ton-mile over the period 1988-1999, although costs do not decline by the same amount each year. ${ }^{24}$ Controls for railcar ownership and the number of junctions between rail lines are significant determinants

\footnotetext{
${ }^{24}$ For instance, these coefficients show an abrupt decline in 1994. This may be partly because the panel is unbalanced and the number of routes in the sample increased by about $75 \%$ in that year.
} 
of marginal cost. Rail car ownership measures the percentage of railcars in the sampled coal shipments that were not owned by the railroad hauling coal. ${ }^{25}$ Use of these cars would lower railroad costs, and, as shown in table 2 , this variable has a negative coefficient $(-2.16)$ that is significantly different from zero at the $1 \%$ level. Marginal cost per ton-mile increases with the number of junctions (interline transfers between railroads) along a route and the coefficient of this variable is positive (0.34) and significantly different from zero at the $1 \%$ level. This outcome is consistent with results presented by Tye (1990).

Five main results emerge from the estimates of the real freight rate per ton-mile equation. First, this equation allows for changes in marginal transportation cost to affect the freight rate differently depending on the extent of market power in the railroad sector. Recall that under competition, a one-unit change in marginal transportation cost leads to an identical one-unit change in the freight rate at all points along the rail line. In contrast, under railroad market power a one-unit change in marginal transportation cost leads to a less than one-unit change in the freight rate for the plants in region I and a one-unit change in marginal transportation costs has no effect on freight rates to plants in region II. Estimates in column (3) show that the coefficient of marginal transportation costs is significantly greater than zero (at 1\%) and that the interaction of marginal transportation cost and the dummy variable indicating route distance greater than 550 miles is negative and significant (at $1 \%$ ). The null hypothesis that these two coefficients add to zero is not rejected at the 1\% level, supporting: (1) the notion that railroads have market power, (2) the division point between region I and region II is at approximately 550 miles with about $90 \%$ of plants in region II, and (3) marginal transport costs affect the freight rate within 550 miles of the mines, but have no effect beyond that point. $^{26}$

Second, the equation permits a test of whether freight rates differ between plants with and without Table A generating units. The

\footnotetext{
${ }^{25}$ These cars might be owned by another railroad or by a utility. ${ }^{26}$ This result rests on a division of routes into two bins, routes less than 550 miles (the shortest $10 \%$ of routes) and routes longer than 550 miles (the longest $90 \%$ of routes). In alternative specifications, the mileage breakpoint defining the bins was increased with the result that the estimate of $\beta_{1}$ (see equation (10)) declines, as would be expected if region II plants are incorrectly classified as region I plants. Dividing routes longer than 550 miles into more bins also was tried and the results were little changed.
}

model predicts that freight rates will not differ between such plants under both railroad competition and monopoly. Under competition, the freight rate always is equated with marginal transportation cost, so that the designation of Table A generating units makes no difference for railroad freight rates. Under monopoly, an increase in the cost of burning high-sulfur coal leads to no change in freight rates in region I. All region I plants burn lowsulfur coal and the railroad's profit maximizing freight rate is simply a mark-up over marginal transportation cost that does not depend on the high-sulfur coal price. In region II, an increase in the cost of burning high-sulfur coal increases freight rates to all buyers, both new and incumbent, whether or not they operate Table A units. Thus, plants with Table A units do not see an increase in freight rates beyond the rate charged to plants with no Table A units. This prediction that freight rates to plants with Table A units are the same as those to plants without Table A units is borne out in the estimates: The coefficient of the dummy variable for plants with Table A generating units is not significantly different from zero at conventional levels.

Using a bargaining model, Busse and Keohane (2007) predict that after the initiation of $\mathrm{SO}_{2}$ emissions trading: (1) delivered prices of PRB coal will be higher at plants with Table A units relative to plants with no Table A units and (2) delivered prices of PRB coal increased by more at plants with Table A units that are closer to mines than at similar plants located at a greater distance from the mines. Because their econometric analysis supports these predictions, these possibilities were tested in expanded specifications of the freight rate equation. When the specification of the freight rate equation is altered from that shown in Table 2 by including interactions of the Table A dummy variable with the dummies for years 1994-1999 (and other equations specified as shown in table 2 ), the estimated coefficient of the interaction with year 1999 was positive and differed significantly from zero at the $1 \%$ level. Coefficients of other interactions did not differ significantly from zero at conventional levels, so in this expanded specification, plants with Table A units did not see higher freight rates beyond those charged to other plants except in 1999. Also, starting from the Table 2 specification, when Table A dummy in the freight rate equation was replaced with interactions between it and two dummy variables for whether a plant was less than 1,100 miles from the PRB mines and whether a plant 
was more than 1,100 miles away, coefficients of the two interaction variables did not differ significantly from zero.

Possible explanations for why these results differ from those presented by Busse and Keohane (2007) are that the analysis in this article: (1) uses the STB data of railroad freight rates rather than FERC 423 data on delivered PRB coal prices and (2) controls unobserved heterogeneity between cross-section units using route-effects, rather than by separately entering mine-effects (origin-effects) and plant-effects (destination-effects). For instance, in the present analysis, inclusion of 353 route-effects better controls for cross-section heterogeneity than would the inclusion sixteen railhead-effects and eighty-seven powerplant effects because the route effects allow the railhead- and power-plant effects to be matched, thus completely removing the effect of distance.

Third, spot sales tend to occur at lower mine-mouth prices than coal sold under either short- or long-term contracts. Under competition, the freight rate is unaffected by a lower mine-mouth price of PRB coal; whereas under monopoly, a one-unit reduction in the minemouth price of PRB coal leads to a less than one-unit increase in freight rates in region I and exactly a one-unit reduction in freight rates in region II. In column (3), the coefficient of spot market sales is positive and significantly different from zero at the $1 \%$ level. This outcome again supports the notion of market power in the railroad sector as lower mine-mouth PRB coal prices secured through spot sales result in higher freight rates. Fourth, time dummies are included to capture a number of unobserved factors (including those previously enumerated such as $\mathrm{SO}_{2}$ permit prices) that vary over time, but not across electric generating plants. Coefficient estimates of the time dummies indicate that on balance these factors led to a significant (at 1\%) decline in freight rates over the period 1988-1999. Implications of this result are further developed in the next subsection. Fifth, the quantity of coal purchased by an electric generating plant is unimportant in determining freight rates.

The third equation in the system estimates the responsiveness of the quantity of PRB coal demanded by power plants to changes in freight rates. Because the quantity of coal purchased does not affect the freight rate, changes in the observed freight rate (per ton mile) can be used to trace out the demand curve. The dependent variable in this equation is expressed as total annual tons of coal purchased per mile of distance from the PRB mines.

Results presented in table 2, column (4) indicates that the previously described declines in freight rates have a positive and significant (at $1 \%$ ) effect on quantity of PRB coal purchased. The elasticity of quantity demanded with respect to a change in the freight rate, evaluated at sample means of these variables, is -3.79 . This estimate indicates that: (1) PRB coal is a close substitute for other fuels used to generate electric power (e.g., high-sulfur coal, natural gas, and oil) whose prices are controlled with time dummies and (2) railroads operate on the elastic portion of the demand schedule for PRB coal, an outcome consistent with railroad market power. Additionally, increases in electric generation capacity have a positive and significant (at 1\%) effect on the quantity of coal demanded. Coefficients of the time dummies reflect a downward trend in the total quantity of PRB coal purchased per mile of distance, possibly because average route length increased over the sample period and delivered quantity declines over distance. The coefficient of the dummy variable for electric generating plants with Table A units, however is not significant at conventional levels. This outcome is consistent with the notion discussed previously that all plants in region II face the same delivered price of PRB coal whether or not they operate Table A units. $^{27}$

\section{Discussion}

Estimates from the econometric model and information provided in the background section can be used in conjunction with the model to make some rough calculations that explain the dramatic increase in utilization of PRB coal in electric power generation in terms of: (1) a market area effect and (2) a fuel substitution effect. The market area effect refers to the small geographic expansion of the railroads' service territory for transporting PRB

\footnotetext{
27 The robustness of this result was checked in three ways. First, the three equation system was reestimated with quantity of coal specified in tons, rather than tons per mile. The coefficient of the Table A dummy did not differ significantly from zero at $5 \%$. Second, the system was reestimated after excluding from the sample 157 observations that involved electric generating plants that opted in to phase I regulations. The opt-in plants were identified from a complete list of such plants furnished by J.-P. Montero. Again, the coefficient of the Table A dummy did not differ significantly from zero at $5 \%$. Third, interactions of the Table A dummy variable with the time dummies also were tried as explanatory variables, however, coefficients of these interaction variables never were significantly different from zero at the $5 \%$ level or lower.
} 
coal that occurred between the years 1988 and 1999. Over the period 1988-1997, the average distance over which PRB coal was transported increased from about 993 miles to 1,037 miles (U.S. Department of Energy, Energy Information Administration 2000, p. 15) and over the period 1988-1999, the length of the longest route in the Carload Waybill sample grew from 1,575 miles to 1,673 miles. Four factors led to this expansion. First, real railroad marginal transportation costs declined $36 \%$ from an average of 11.47 mills per ton-mile in 1988 to an average of 7.34 mills per ton-mile in 1999. Second, the real mine-mouth price of PRB coal declined $50 \%$ from $\$ 0.64$ per million BTUs in 1988 to \$0.32 per million BTUs in 1999 (Hill and Associates 2000). Third, more stringent environmental regulation brought about by the introduction of $\mathrm{SO}_{2}$ emission permits raised the overall cost of burning high-sulfur coal by about $\$ 0.15 .^{28}$ Fourth and set against the first three factors, high sulfur coal prices declined between the years 1988 and 1999 . Among utilities purchasing PRB coal identified in the Carload Waybill Sample, FERC 423 records indicate that the average real delivered price of non-Wyoming coal, an estimate of the high-sulfur coal price net of $\mathrm{SO}_{2}$ emission permit costs, declined from $\$ 1.91$ per million BTUs in 1988 to $\$ 1.27$ per million BTUs in 1999. Inclusive of $\mathrm{SO}_{2}$ permit costs, the estimated 1999 price of one million BTUs of nonWyoming coal was $\$ 1.42$.

To more clearly illustrate how these factors coalesce, consider the example of hauling one million BTUs of $8800 \mathrm{BTU} / \mathrm{lb}$. PRB coal hauled a distance of 1,600 miles in 1988 As indicated previously, a route of this length represents about the maximum distance that PRB coal was transported during the late 1980s. Adding the railroad transportation cost of making this delivery $(\$ 1.04=\$ 0.01742 \times$ $(1,000,000 / 8800) \times 1600)$ to the mine-mouth price of PRB coal (\$0.64), yields \$1.68, which is lower than the price (\$1.91) of non-Wyoming coal prevailing at that time. Thus, railroads appear to have had an incentive to haul coal greater distances than 1,600 miles prior to the enactment of the Clean Air Act Amendments of 1990. This incentive increased throughout the 1990s, and by 1999, the delivered cost of

\footnotetext{
${ }^{28}$ This calculation assumes that: (1) nonWyoming coal averages $12,000 \mathrm{BTU} / \mathrm{lb}$., (2) nonWyoming coal has 1.5 more pounds of $\mathrm{SO}_{2}$ per million BTUs than allowed under phase I compliance rules ( 2.5 pounds of $\mathrm{SO}_{2}$ per million BTUs), and (3) the market price of a permit to emit one ton of $\mathrm{SO}_{2}$ averaged \$195 in 1999.
}

one million BTUs of PRB coal to a utility 1,600 miles distant had fallen by $\$ 0.64$ in real terms to $\$ 1.04$ (the mine-mouth price of $\$ 0.32$ plus railroad transportation cost of \$0.72). The delivered price of high-sulfur coal (inclusive of $\mathrm{SO}_{2}$ emission permit costs) also fell over this period, but by a lesser amount $(\$ 0.49$; from $\$ 1.91$ to $\$ 1.42$ ), and the price per million BTUs at this distance fell by more for delivered PRB coal than for high-sulfur coal even when no accounting is made for the shadow cost of $\mathrm{SO}_{2}$ emission permits. In summary, it appears that incentives already in place in the late 1980 s, together with price declines in the mine-mouth price of PRB coal and declines in railroad transportation cost, can explain much of the small geographic expansion in the railroad service territory for PRB coal.

What other factors explain the rapid expansion of PRB coal utilization? The coefficient estimates of the time dummies in the table 2 , column (3) regression imply that, for a representative shipment of $8800 \mathrm{BTU} / \mathrm{lb}$. PRB coal to a utility 1,600 miles distant, the real freight rate fell by approximately $\$ 0.34$ per million BTUs over the period 1988-1999, reducing the delivered price per million BTUs of PRB coal in real terms by $\$ 0.66(\$ 0.34+\$ 0.32)$. This $35 \%$ decline in price not only exceeded the $26 \%$ decline in the (permit-inclusive) real price of high-sulfur coal; it also exceeded the real price declines that occurred in both natural gas $(12 \%)$ and crude oil (15\%) over the period. Given the estimated price elasticity of demand for PRB coal of -3.79 , this change in relative prices suggests that power plant operators substituted heavily in the favor of PRB coal and away from the use of other alternative fuels for the generation of electric power throughout the market area. This substitution could have occurred, for example, through utilization of coal mixtures tilted toward heavier use of PRB coal and using PRB coal-fired generating units more intensively.

\section{Summary and Conclusion}

This article examines possible explanations for the dramatically increased utilization of PRB low-sulfur coal to generate electric power that occurred during the late 1980s and 1990s. Effects of environmental policy, costs, and relative prices are examined using a threesector model of coal production, transportation, and consumption that emphasizes the role of railroads in hauling coal to spatially 
distributed utilities. The relative importance of each of the various explanations depends critically on whether (and to what extent) railroads exercise market power in setting freight rates on low-sulfur coal.

Key findings from this study suggest that: (1) railroads held market power over delivered low-sulfur coal prices, (2) the geographic market for PRB coal expanded mainly because of substantial declines in both the real mine-mouth price of PRB coal and the real marginal cost of rail transportation, (3) the decline in both the mine-mouth price of PRB coal together with the decline in railroad freight rates induced power plant operators to substitute PRB coal for high-sulfur coal as well as for other fuels because demand for PRB coal is price elastic. More stringent environmental policy on $\mathrm{SO}_{2}$ emissions also appears to have led to increased utilization of PRB coal, however, the effect of policy is moderated by the existence of railroad market power. These results are broadly consistent with the view that much of the increased utilization of PRB lowsulfur coal was due to the operation of market forces rather than to changes in environmental policy.

\section{References}

Association of American Railroads, Business Services Division. 2000. User Guide for the 1999 Surface Transportation Board Carload Waybill Sample. Washington DC.

Atkinson, S., and J. Kerkvliet. 1986. "Measuring the Multilateral Allocation of Rents: Wyoming Low Sulfur Coal." Rand Journal of Economics 17:416-30.

BXG, Inc. 1985a. Powder River Basin Coal Supply and Demand: 1985 Update. Boulder, CO.

- 1985b. Illinois Basin Supply and Demand: 1983-1993. Boulder, CO.

Borenstein, S. 1989. "Hubs and High Fares: Dominance and Market Power in the U.S. Airline Industry." Rand Journal of Economics 20:34465.

1990. "Airline Mergers, Airport Dominance, and Market Power." American Economic Review 80:400-04.

Brander, J.A., and A. Zhang. 1990. "Market Power in the Airline Industry: An Empirical Investigation." Rand Journal of Economics 21:56783.

Busse, M.R., and N.O. Keohane. 2007. "Market Effects of Environmental Regulation: Coal, Rail- roads, and the 1990 Clean Air Act," Rand Journal of Economics 38:1159-179.

Carlson, C., D. Burtraw, M. Cropper, and K.L. Palmer. 2000. "Sulfur Dioxide Control by Electric Utilities: What Are the Gains from Trade? Journal of Political Economy 108:1292326.

Code of Federal Regulations. 2001. Procedures for the Release of Waybill Data, Title 49, Chapter X, Part 1244.9, Washington DC.

Darmstadter, J. 1999. "Innovation and Productivity in U.S. Coal Mining." In R. David Simpson, ed. Productivity in Natural Resource Industries. Washington DC: Resources for the Future, pp. 35-72.

Ellerman, A.D., and J.-P. Montero. 1998. "The Declining Trend in Sulfur Dioxide Emissions: Implications for Allowance Prices." Journal of Environmental Economics and Management 36:26-45.

Ellerman, A.D., P.L. Joskow, R. Schmalensee, J.-P. Montero, and E.M. Bailey. 2000. Markets for Clean Air: The U.S. Acid Rain Program. Cambridge: Cambridge University Press.

Federal Energy Regulatory Commission. Various years. Monthly Report of Cost and Quality of Fuels for Electric Plants. Washington DC.

Granitz, E., and B. Klein. 1996. "Monopolization by 'Raising Rivals' Costs': The Standard Oil Case." Journal of Law and Economics 39:1-47.

Greene, W.H. 2003. Econometric Analysis. 5th ed. Upper Saddle River, NJ: Prentice-Hall.

Greenhut, M.L., and H. Ohta. 1972. "Monopoly Output Under Alternative Spatial Pricing Techniques." American Economic Review 62:705-13.

Greenstone, M. 2002. "Did the Clean Air Act Cause the Remarkable Decline in Sulfur Dioxide Concentrations?" Journal of Environmental Economics and Management 47:585-611.

Hill and Associates. 2000. Powder River Basin Coal Supply, Demand and Prices. Annapolis, MD.

- 2003. Illinois Basin Coal Supply Demand \& Price Trends to 2013: An Analysis of the Indiana, Illinois, and West Kentucky Coalfields. Annapolis, MD.

Joskow, P.L. 1987. "Contract Duration and Relationship-Specific Investments." American Economic Review 77:168-85.

Joskow, P.L., R. Schmalensee, and E.M. Bailey. 1998. "The Market for $\mathrm{SO}_{2}$ Emissions." American Economic Review 88:669-85.

Joskow, P.L., and R. Schmalensee. 1998. "The Political Economy of Market-Based Environmental Policy: The U.S. Acid Rain Program.” Journal of Law and Economics 41:37-83.

Kerr, R.A. 1998. "Acid Rain Control: Success on the Cheap." Science 282:1024-7. 
Kim, E.H., and V. Singal. 1993. "Mergers and Market Power: Evidence from the Airline Industry." American Economic Review 83:54969.

Kolstad, C.D., and F.A. Wolak, Jr. 1983. "Competition in Interregional Taxation: The Case of Western Coal." Journal of Political Economy 91:443-60.

Montero, J.-P. 1999. "Voluntary Compliance with Market-Based Environmental Policy: Evidence from the U.S. Acid Rain Program." Journal of Political Economy 107:998-1033.

Novshek, W. 1985. "On the Existence of Cournot Equilibrium." Review of Economic Studies 52:85-98.

Savage, I. 1995. "Panzar and Rosse Style Tests of Market Structure in the U.S. Motor Carrier In- dustry." Logistics and Transportation Review 31:135-43.

Tye, W.B. 1990. The Theory of Contestable Markets: Applications to Regulatory and Antitrust Problems in the Rail Industry. New York: Greenwood Press.

U.S. Department of Energy, Energy Information Administration. Various years. Annual Coal Report. Washington DC.

- 2000. Energy Policy Act Transportation Study: Final Report on Coal Transportation. Washington DC. 2003. State Coal Profiles. Washington DC.

Wolak, F.A., Jr., and C.D. Kolstad. 1988. "Measuring Relative Market Power in the Western U.S. Coal Market Using Shapley Values." Resources and Energy 10:293-314. 